Journal of Animal and Veterinary Advances 9 (7): 1173-1174, 2010

ISSN: $1680-5593$

(C) Medwell Journals, 2010

\title{
The Biochemical Parameters Having Economic Importance in Sheep and Fish Meats
}

\author{
M. Kayim \\ Department of Aquaculture, Faculty of Fisheries, Tunceli University, Turkey
}

\begin{abstract}
In this study, 10 meat samples from fish (Trachurus trachurus, L. 1758) and sheep (Akkaraman) were used. In the experiment, the used fish meat was a total body meat. However, the sheep longissimus muscle (lean) from 6th rib cut was sampled for determination of chemical components. The concentrations of total fat were lower $(\mathrm{p}<0.01)$ for fish than sheep. However, the concentrations of $\mathrm{pH}$ were also lower $(\mathrm{p}<0.05)$ for sheep material. There were no effects of animal species on the moisture concentrations. The rates of ash were lower $(\mathrm{p}<0.01)$ for sheep group. The $\mathrm{pH}$ concentrations close to neutral in meat from fish may be advantage for eating quality. However, this $\mathrm{pH}$ level is disadvantage for shelf life of product. However, the high amounts of fat in the sheep meats may have a negative effect upon consumer's preference and health.
\end{abstract}

Key words: Biochemical parameters, meat, fish, sheep, economic, Trachurus trachurus

\section{INTRODUCTION}

Comprehensive studies have revealed large differences among meats for most bioeconomic traits (Gregory et al., 1982; Cundiff et al., 1986). However, chemical findings on meat from different animal species were not available for predicting of economic merits. Recently, in addition to economic results, particular attention has focused on the health problems associated with chemical components such as fat, cholesterol and $\mathrm{pH}$ in animal products. Studies of the chemical composition of milk (Cetin et al., 2007; Cimen et al., 2007, 2008) and meat (Kilicel and Gokalp, 2005) have made a considerable contribution to advances in developing and utilizing of the animal products. The changes in meat biochemical components from different animal species for retail consumers have not been discussed (Sweeter et al., 2005). According to NCBA (2004), roughly $70-80 \%$ of all meats are prepared in the home, so a large percentage of meat is sold at the retail levels.

Identifying an optimum meat source according to biochemical parameters at the retail level may allow for production of a more uniform product in the retail setting and allow producers to make sound decisions on the appropriate meat of animals. Chemical components of meat may be important selection criteria for economic meat production. Most relationship between the chemical parameters from blood, milk or meat of animal material and product traits were in the well-known directions and reflected the well-orchestrated endocrine changes and metabolic adaptations (Reist et al., 2002). There were no reports on chemical components of meats from different animal species for economic merits. Therefore, these parameters have been obtained in this study.

\section{MATERIALS AND METHODS}

In this study, 10 meat samples from fish (Trachurus trachurus, L. 1758) and sheep (Akkaraman) were used. The study was conducted in Tokat in 2008. The sheep and fish meats in this study were obtained from a supermarket and the origin of the fish was Gelibolu, Çanakkale, on the west coast of Turkey named Marmara Region. In the experiment, the used fish meat was a total body meat. However, the sheep longissimus muscle (lean) from 6 th rib cut was sampled for determination of chemical components. The meat samples from animals were ground and sampled for determination of chemical components. Ground samples were analyzed and determined using standard procedures, for ash (AOAC, 1993), protein (Kjeldahl), fat (Hanson and Olley, 1963), pH (pH meter) and moisture (Oksuz et al., 2008).

All of data are indicated as mean \pm SEM. Comparisons were done by using Independent samples t-test with help of the SPSS (Norusis, 1993).

\section{RESULTS AND DISCUSSION}

Means of chemical parameters of meats from different animal species were shown in Table 1. As shown in Table 1, the concentrations of total fat were lower $(p<0.01)$ for fish than sheep. However, the concentrations of $\mathrm{pH}$ were also lower $(p<0.05)$ for sheep material. There were no effects of animal species on the moisture concentrations. The rates of ash were lower $(\mathrm{p}<0.01)$ for sheep material. The chemical components in the meats of both groups were compatible with the report of Kaneko et al. (1997) for sheep and fish meats. In this study, the $\mathrm{pH}$ concentrations close to neutral of meat from fish may be advantage for eating quality. However, this $\mathrm{pH}$ level is 
$\underline{\text { Table 1: Biochemical parameters of meats from different animal materials }}$ Animal

materials Moisture (\%) Ash (\%) $\quad$ Fat (\%) $\quad$ Protein (\%) $\quad \mathrm{pH}$

\begin{tabular}{llllll}
\hline Sheep & $73.3 \pm 1.1$ & $0.9 \pm 0.1$ & $5.3 \pm 0.2^{* * *}$ & $17.2 \pm 0.5$ & $5.9 \pm 0.3$
\end{tabular}

\begin{tabular}{llllll} 
Fish & $72.3 \pm 0.8$ & $1.5 \pm 0.2^{* * *}$ & $1.7 \pm 0.1$ & $21.0 \pm 0.2^{* * *}$ & $6.2 \pm 0.1^{*}$ \\
\hline
\end{tabular}

* $\mathrm{p}<0.05 ; * * \mathrm{p}<0.01$ (within same column)

disadvantage for shelf life of product. The shorter shelf life negatively effects on salability of meat. The meat quality traits must include suitable $\mathrm{pH}$ that indicates eating quality and shelf life. Lower $\mathrm{pH}$ value is related to greater losses during further meat processing and high $\mathrm{pH}$ value is related to shorter shelf life but also better eating quality (Gregory et al., 1994). However, the high amounts of fat in the sheep meats may have a negative effect upon consumer's preference and health. The consumer preference on meat salability is reduced when meats have excessively fat (Amer et al., 1997). While increases in fat and $\mathrm{pH}$ may be desirable over some range, excessive levels of these traits can be undesirable.

The differences in chemical components provide a potential opportunity to manipulate bioeconomic pathways in meat to enhance quality characteristics and consequently, commercial gain. The relative returns from meat vary from animal to animal and there is a need for the special classification of all meats from different animal species according to their biochemical parameters to achieve maximum economic return.

\section{CONCLUSION}

The changes in chemical parameters of meats may be important selection criteria for economic merits and consumer preference. Further data on meats from different animal species such as sheep, fish, pig, cow and goat are also needed to improve the interpretation of interrelationships between chemical components and marketing conditions of meat. Meat quality traits including fat and $\mathrm{pH}$ will be important in determining meat price and profits in the near future and perhaps in maintaining a market in the more distant future.

\section{REFERENCES}

AOAC, 1993. Official Methods of Analysis. 15th Edn., Association of Official Agricultural Chemistry, Washington DC. USA.

Amer, P.R., G.C. Emmans and G. Simm, 1997. Economic values for carcase traits in UK commercial beef cattle. Livest. Prod. Sci., 51: 267-281.

Cetin, M., M. Cimen, M. Dilmac, E. Ozgoz and M. Karaalp, 2007. Studies of biochemical parameters of milk of sheep milked by machine during early lactation period. Asian J. Chem., 19: 2135-2140.
Cimen, M., M. Karaalp and S. Sahin, 2007. Relationships between some blood and milk components in early lactation in non-dairy sheep. Asian J. Chem., 19: 600-606.

Cimen, M., M. Karaalp and M. Elmastas, 2008. Effect of breed and live weight on milk fat depression in sheep. Asian J. Chem., 20: 3885-3888.

Cundiff, L.V., K.E. Gregory, R.M. Koch and G.E. Dickerson, 1986. Genetic diversity among cattle breeds and its use to increase beef production efficiency. Proc. 3rd World Cong. Genet. Appl. Livest. Prod., 9: 271-282.

Gregory, K.E., L.E. Cundiff and R.M. Koch, 1982. Comparison in crossbreeding systems and breeding stocks used in suckling herds of continental and temperate areas. Proceedings of the 2nd World Congress on Genetic Applications to Livestock Production, (GALP'82), Spain, pp: 482-503.

Gregory, K.E., L.E. Cundiff, R.M. Koch, M.E. Dikeman and M. Koohmaraie, 1994. Breed effects and retained heterosis for growth, carcass and meat traits in advanced generations of composite populations of beef cattle. J. Anim. Sci., 72: 833-850.

Hanson, S.W.F. and J. Olley, 1963. Application of the bligh and dyer method of lipid extraction to tissue homogenates. Proc. Biochem. Soc., 89: 101-102.

Kilicel, F. and F. Gokalp, 2005. Determination of some heavy metal levels in muscle tissues of lake Van fish (Chalcalburnus tarichi). Asian J. Chem., 17: 2425-2429.

Kaneko, J.J., J.W. Harvey and M.L. Bruss, 1997. Clinical Biochemistry of Domestic Animals. 5th Edn., Academic Press, New York, pp: 39-386.

NCBA. (National Cattlemen's Beef Association), 2004. Beef bytes. http://www.beef.org/Beef $\% 20$ Bytes $\% 20$ Eating\%20Beef.pdf.

Norusis, M.J., 1993. SPSS for Windows: Base System User's Guide. 1st Edn., SPSS Inc., Chicago, ISBN-10: 0131788566, pp: 710-800.

Oksuz, A., A. Ozeren and A. Atlar, 2008. Palamut (Sarda sarda) Balıklarının Kırmızı ve Beyaz Kaslarındaki Bazı Biyokimyasal Parametrelerinin Karp1laptur1ması. J. Fish. Sci., 2: 639-644.

Reist, M., D. Erdin, D. von Euw, K. Tschuemperlin and H. Leuenberger et al., 2002. Estimation of energy balance at the individual and herd level using blood and milk traits in high-yielding dairy cows. J. Dairy Sci., 85: 3314-3327.

Sweeter, K.K., D.M. Wulf and R.S. Maddock, 2005. Determining the optimum beef longissimus muscle size for retail consumers. J. Anim. Sci., 83: 2598-2604. 